HüHN, M. (1979): Beiträge zur Erfassung der phänotypischen Stabilität. I. Vorschlag einiger auf Ranginformationen beruhender Stabilitätsparameter. EDV in Medizin und Biologie 10, 112-117.

JENSEN, J. S. and J. K. HANSEN (2008): Geographical variation in phenology of Quercus petraea (Matt.) Liebl and Quercus robur L. oak grown in a greenhouse. Scan. J. For. Res. 23: 179-188.

JENSEN, J. (1993): Variation of growth in Danish provenance trials with oak (Quercus robur L and Quercus petraea Mattuschka Liebl). Ann. For. Sci. 50, Suppl. 1 (Genetics of oaks): 203-207.

Jensen, J. (2000): Provenance Variation in Phenotypic Traits in Quercus robur and Quercus petraea in Danish Provenance Trials. Scan. J. For. Res., 15: 297-308.

JENSEN, J. S. and J. D. DeAns (2004): Late autumn frost resistance of twelve north European provenances of Quercus species. Scand. J. For. 19, 5: 390-399.

JöRGENSEN, J. (1994): Application of in vitro Techniques for Conservation and Breeding of Oak, Beech and Horse Chestnut. In: First Joint Korean-German Symposium on Forest Genetics. Inchon Memory Hall, University, Seoul, Korea. 175-205.

KLEINSCHMIT, J. (1986): Oak breeding in Germany, experiences and problems. In: Proc. Joint Meeting of Working Parties Breeding Theory, Progeny Testing and Seed Orchards; October 12-17, 1986. Williamsburg, Virginia. 250-258.

KLEINSCHMIT, J. (1993): Intraspecific variation of growth and adaptive traits in European oak species. Ann. For Sci. 50, Suppl. 1 (Genetics of oaks): 166-185.

KLEINSCHMIT, J. (1999): Breeding strategies for hardwoods: oak, cherry and birch. In: Strategies for Improvement of Forest Tree Species. In: Proc. Symposium on Forest Genetics. March $9^{\text {th }} 1998$ Trinity College Dublin, Ireland, pp. 37-62.
Kleinschmit, J. and J. Svolba (1979): Möglichkeiten der züchterischen Verbesserung von Stiel- und Traubeneichen $(Q$. robur und $Q$. petraea) III. Nachkommenschaftsprüfung von Eichenzuchtbäumen. Allgemeine Forst- und Jagdzeitung, 150: 111-120.

KLEINSCHMIT, J. and J. SvolbA (1995): Intraspezifische Variation von Wachstum und Stammform bei Quercus robur und Quercus petraea. In: Mitteilungen aus der Forstlichen Versuchsanstalt Rheinland-Pfalz. Nr. 34; 75-99.

KLEINSCHMIT, J. and J. SvolBA (1996): Intraspecific variation of growth and stem form in Quercus robur and Quercus petraea. In: KREMER, A., MUHS, H. (Eds.), Interand Intraspecific Variation in European Oaks: Evolutionary Implications and Practical Consequences. European Commission, EUR16717N, Brussels, pp. 217-238. ISBN 92-827-5993-8.

KRAHL-URBAN, J. (1957): Über Eichenprovenienzversuche. Silvae Genet. 6: 15-31.

Kremer, A., J. Kleinschmit, J. Cottrell, E. P. Cundall, A. Ducousso, A. O. König, A. J. Lowe, R. C. Munro, R. J. Petit and B. R. StePhan (2002): Is there a correlation between chloroplastic and nuclear divergence, or what are the roles of history and selection on genetic diversity in European oaks? For. Ecol. and Manage. 156: $75-87$.

LIEPE, K. (1993): Growth chamber trial on frost hardiness and field trial on bud burst of sessile oak (Quercus petraea Liebl and Q. robur L.). Ann. For. Sci. 50, Suppl. 1 (Genetics of oaks): 208-214.

LIESEBACH, H. and I. ZASPEL (2004): Phenotypical and genetic characteristics of sessile oak (Quercus petraea (Matt.) Liebl.) seedlings after storage of acorns. Forest Genetics, 11: 163-171.

\title{
Genetic Variation and Tree Improvement of Konishii fir (Cunninghamia lanceolata (Lamb.) Hook. var. konishii) in Taiwan
}

\author{
By Jeng-Der Chung ${ }^{1)}$, Gordon Nigh ${ }^{2)}$, Ching-Te Chien ${ }^{1)}$ and Cheng C. Ying $^{2), 3)}$
}

(Received $23^{\text {th }}$ August 2010)

\begin{abstract}
We analyzed a 21-year old progeny test of Konishii fir (Cunninghamia lanceolata (Lamb.) Hook. var. konishii) involving 75 families. Tree height and diameter at breast height $(\mathrm{DBH})$ were periodically recorded. At age

\footnotetext{
1) Taiwan Forestry Research Institute, 53 Nan-Hai Road, Taipei, Taiwan 10066.

2) BC Ministry of Forests and Range, Research, Innovation and Knowledge Management Branch, P.O. Box 9519, Stn. Prov. Govt., Victoria, B.C., Canada V8W 9C2.

$\left.{ }^{3}\right)$ Visiting scientist at the Taiwan Forestry Research Institute
} and corresponding author. E-Mail: cying@telus.net.
\end{abstract}

21 , average height, $\mathrm{DBH}$, and volume were $15.2 \mathrm{~m}$, $20.2 \mathrm{~cm}$, and $278 \mathrm{dm}^{3}$, respectively. At this age, family accounted for 9,12 , and $11 \%$ of the total variance in height, $\mathrm{DBH}$ and volume, respectively. Also at age 21 , individual tree heritability was $0.35,0.49$, and 0.45 for height, DBH and volume, respectively, and family heritability was $0.53,0.69$, and 0.66 for the three respective characteristics. The age trend for all genetic parameters was more stable for DBH than for height and volume. Family (backward) selection for $\mathrm{DBH}$ at age 21 resulted in a $9.6 \%$ gain and indirectly 5.1 and $21.0 \%$ gains for height and volume, respectively, compared to 5.2 and $20.1 \%$ gains for height and volume, respectively, when selection for these characteristics is done directly. DBH 
is an effective proxy trait for selection in growth. $\mathrm{DBH}$ is also less susceptible than height to typhoon damage, which frequently afflicts tree plantations in Taiwan. Therefore, DBH should be considered as the primary trait for selection for Konishii fir in Taiwan. Konishii fir is a genetically variable species despite its limited geographic range, and is fast growing which makes it a viable candidate species for tree improvement.

Key words: Konishii fir, genetic variation, tree improvement, Taiwan.

\section{Introduction}

Taiwan is a subtropical island (Figure 1) with a total land area of approximately 36,000 square kilometers. About $35 \%$ of the island is above $1,000 \mathrm{~m}$ with over 50 mountains above $3,000 \mathrm{~m}$ in elevation. This mountainous topography greatly increases the complexity of the local climate and creates diverse habitats resulting in a rich forest flora with over 4,000 woody species of both angiosperms and gymnosperms (CHANG et al., 1979; HsU et al., 2004). Forests dominate the vegetative landscape of the island. Frequent typhoons bring large amounts of rain and strong winds, which play an important role in ecosystem renewal as well as being a destructive disturbance to forests. These geo-climatic and bio-ecological constraints pose difficult challenges for forest management, including operational tree improvement.

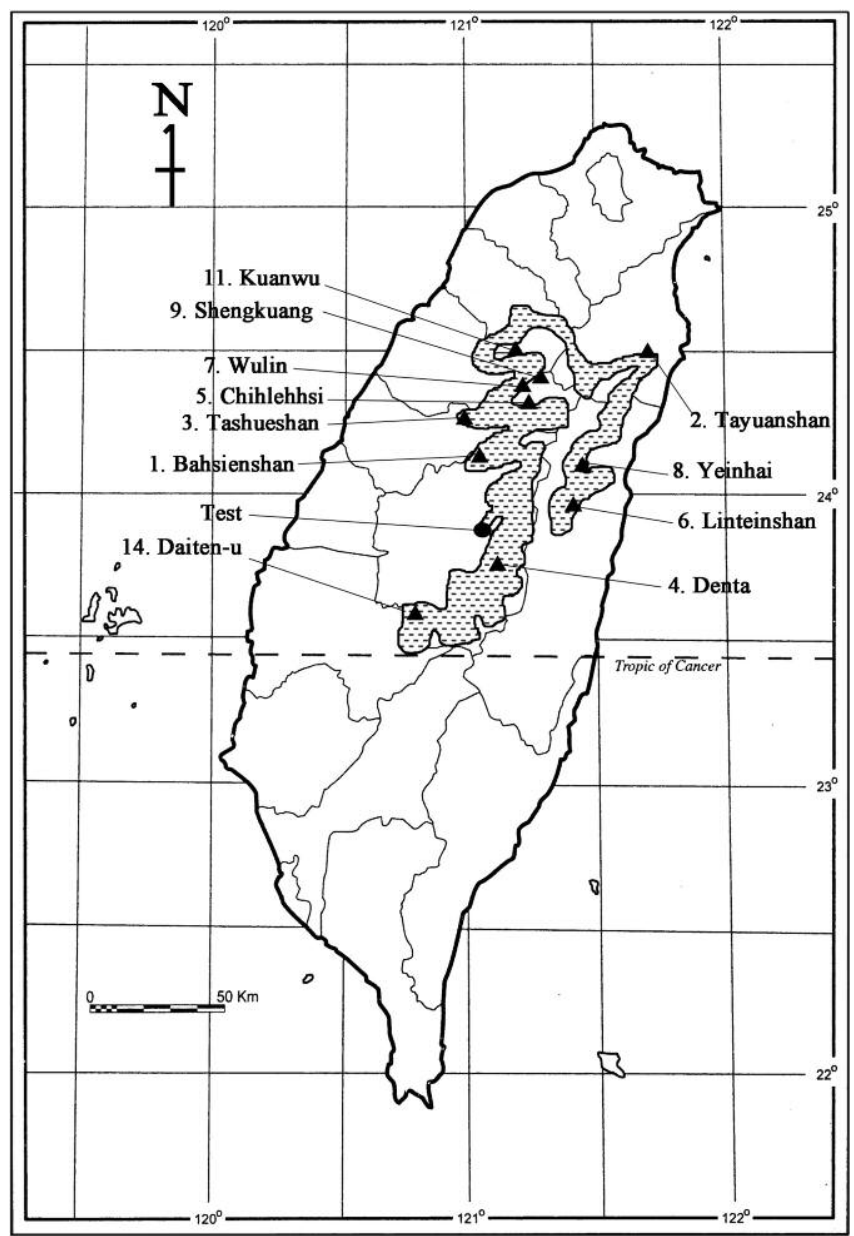

Figure 1. - Map showing the location of the samples and the range of Konishii fir (the shaded area) in Taiwan.
Konsihii fir (Cunninghamia lanceolata (Lamb.) Hook. var. konishii) is one of the most commonly planted timber species in Taiwan. Its taxonomical status as a species has been debated. Molecular evidence indicates that Konishii fir is phenetically linked to China fir (Cunninghamia lanceolata) and is not sufficiently differentiated to be an independent species (LIN et al., 1998; LU et al., 1999; HwANG et al., 2003; CHUNG et al., 2004). Also, there is no evidence that effective reproductive isolation has evolved (YANG and CHUNG, 1999). However, they are different morphologically (LIU et al., 1988). Taiwan Strait, which was formed approximately 3.5 million years ago (LIU, 1972; TsukADA, 1967), lies between Taiwan and Mainland China and has made gene migration from continental China to Taiwan impossible. This long period of isolation may have facilitated the morphological divergence, but not in supposedly neutral genemarkers. Taxonomically, it is now generally accepted that China fir is the ancestor species of Konishii fir, and the latter is a subspecies endemic to Taiwan (LIU et al., 1988; Lu et al., 1999). Konishii fir is also called Luanta fir, after the Luanta Mountain in central Taiwan where it was first found. Its natural distribution is limited to central Taiwan (latitude $23^{\circ} 30^{\prime}$ and $24^{\circ} 30^{\prime}$ above 1,000 m, Figure 1).

The tree improvement program in Taiwan started in the early 1970s. A series of provenance and genetic tests and seed orchards were established for conifer timber species including Konishii fir. The program did not thrive, partly due to the small land base and partly due to the large number of potential target species (over a dozen including broadleaf species) that were available for improvement in terms of desirable wood properties for high-value products such as furniture, panel, veneer, etc. Also, the rapid change in industrial structure and socio-economic factors in Taiwan has reduced wood manufacturing, once a core economic contributor, to a less significant industry. However, the tests and seed orchards have been well maintained and were periodically measured (CHUNG et al., 2009).

Interest in tree improvement was rekindled in recent years out of concerns over the impacts of global warming (Hsu and CHEN, 2002; QUAN et al., 2009) and also the dwindling forest resources in neighboring countries in Southeast Asia, a major timber source for Taiwan in the past decades. Analyses of the growth data from these progeny tests, which are now close to rotation age, can provide the basic information on genetic variability, heritability, selection regime, and potential gain for assessing the short and long term viability for tree improvement.

Konishii fir is a fast growing timber species with a dominant central stem. It can sustain over one centimeter of annual diameter growth and produce $300 \mathrm{~m}^{3}$ of merchantable volume per hectare at age 30 (LIU et al., 1979). The diameter growth of the trees from the Konishii provenance test was in decline. Consequently, CHUNG et al. (2009) used growth curve analyses as a tool for assisting with decisions about what age to make selections. In this report, we analyze the data focusing on genetic parameter estimates to recommend approaches for the genetic improvement of Konishii fir. 
Table 1. - Measurement schedule.

\begin{tabular}{|c|c|c|c|c|c|c|c|}
\hline $\begin{array}{l}\text { Year } \\
\text { month }\end{array}$ & $\begin{array}{l}\text { Plantation } \\
\text { age (yrs) }\end{array}$ & Height & Diameter & $\begin{array}{l}\text { Year/ } \\
\text { month }\end{array}$ & $\begin{array}{l}\text { Plantation } \\
\text { age (yrs) }\end{array}$ & Height & Diameter \\
\hline $73 / 08$ & 0.5 & $\checkmark$ & & $80 / 01$ & 7.0 & $\checkmark$ & $r$ \\
\hline $74 / 12$ & 2.0 & $\checkmark$ & & $81 / 01$ & 8.0 & $\checkmark$ & $\checkmark$ \\
\hline $75 / 06$ & 2.5 & $\checkmark$ & $\checkmark$ & $87 / 01$ & 14.0 & & $\checkmark$ \\
\hline $76 / 01$ & 3.0 & $\checkmark$ & & $94 / 01^{4}$ & 21.0 & $\checkmark$ & $\checkmark$ \\
\hline $77 / 01$ & 4.0 & $\checkmark$ & & $97 / 01$ & 24.0 & $\checkmark$ & $\checkmark$ \\
\hline $78 / 01$ & 5.0 & $\checkmark$ & $\checkmark$ & $99 / 01$ & 26.0 & $\checkmark$ & $\checkmark$ \\
\hline $78 / 12$ & 6.0 & $\checkmark$ & $\checkmark$ & & & & \\
\hline
\end{tabular}

$\checkmark$ Measured

${ }^{a}$ Individual tree identities were not recorded.

\section{Materials and Methods}

\section{The Test Plantation}

Four provenance tests were established, three of which were abandoned because of low initial survival. The test reported here was planted in January 1973 in central Taiwan at an elevation of 1,044 m. Ninety-five families from 12 provenances of Konishii fir (Figure 1) and one China fir source were tested in a randomized complete block design with five blocks. Each family was planted in a 10 -seedling row plot at $2 \times 2 \mathrm{~m}$ spacing (CHung et al., 2009). The planting stock was $1+1$ bareroot seedlings. The test was spaced in 1989 after 16 growing seasons and about one-third of the trees were removed to reduce inter-tree competition. The seeds were from natural stands except the China fir seed. For the 'purity' of genetic parameter estimates, we excluded the China fir source (20 families) from our analysis, leaving growth data from 75 Konishii fir families to analyze.

\section{Data}

Diameter at $1.3 \mathrm{~m}(\mathrm{DBH}, \mathrm{cm})$ was measured 9 times and total height (HT, m) was measured 12 times (Table 1). Individual tree identity (tree position in the family plot) was not recorded at the age 21 measurement. The number of trees that were measured in each plot varied at different ages. At the ages when only partial measurements were taken, about five trees (usually the same trees) in each plot were measured. The last measurement was done in 1999 at age 26, which is very close to the harvest age of about 30 years (KuO, 1995). A severe typhoon in 1996 caused considerable damage to the test plantation, which mainly affected height (CHung et al., 2009). The final measurement before the typhoon was in 1994 at age 21 , which served as the target age in our calculations of genetic response to selection. However, the trees were already exhibiting asymptotic growth before the typhoon, most evident in $\mathrm{DBH}$ (CHUNG et al., 2009). In this report we focus the analyses on the growth before the typhoon.

Individual tree volumes (VOL, $\left.\mathrm{dm}^{3}\right)$ were estimated using the following equation (FENG and JENG, 1992):

$$
\mathrm{VOL}=0.0000702 \times\left(\mathrm{DBH}^{1.8942224}\right) \times\left(\mathrm{HT}^{0.8869654}\right) .
$$

\section{Estimates of variance components and genetic parameters}

Growth traits at different ages were analyzed according to the following model:

Table 2. - Expected mean squares for the variance components assuming all the effects are random.

\begin{tabular}{|l|l|} 
Source & $\begin{array}{l}\text { Expected mean squares } \\
\text { Block }\end{array}$ \\
$\sigma^{2}+k_{1} \sigma_{t b}^{2} \cdot k_{2} \sigma_{b}^{2}$
\end{tabular}

a The $k$ coefficients are from procedure GLMs estimate function IV. 


$$
\mathrm{Y}_{\mathrm{ijk}}=\mu+\mathrm{B}_{\mathrm{i}}+\mathrm{F}_{\mathrm{j}}+\mathrm{BF}_{\mathrm{ij}}+\varepsilon_{\mathrm{ijk}}
$$

where $\mathrm{Y}_{\mathrm{ijk}}$ is $\mathrm{HT}, \mathrm{DBH}$, or VOL of tree $\mathrm{k}$ from the $\mathrm{j}^{\mathrm{th}}$ family planted in the $i^{\text {th }}$ block, $\mu$ is the overall mean, $B$ is the random block effect, $\mathrm{F}$ is the random family effect, $\mathrm{BF}$ is their interaction and $\varepsilon$ is the error term. The expected mean squares (EMS) for the model terms are given in Table 2.

We did not include provenance effect because provenance variation is not correlated with its geographic origin and accounts for small amount of the total variance in our previous analyses (CHUNG et al., 2009). In other words, provenance variation is not geographically structured and thus not adaptive in nature (LIN et al., 1998). We, therefore, treated the 75 families as representative samples of the species in our analyses.

We employed the SAS procedure MIXED with the REML method to estimate the variance components (VCs) and predict the family means. Procedure MIXED does not allow the estimates of the VCs to be negative and produces best linear unbiased predictions (LITTELL et al., 1996). Variance component estimation also does not require the data to be strictly normally distributed (SEARLE, 1971). We also subjected the same data to an analysis of variance using procedure GLM in SAS with estimate function IV based on the same linear model described above. The error VCs were identical to those obtained from procedure MIXED, the VCs for the block and family interaction were almost identical, and the $\mathrm{VCs}$ for the main factors were slightly different. We reported the VC estimates from procedure MIXED and used the component coefficients (Table 2) from procedure GLM to derive the heritabilities and genetic gains.

Individual tree heritability $\left(\mathrm{h}^{2}{ }_{\mathrm{i}}\right)$ and family heritability $\left(\mathrm{h}_{\mathrm{f}}^{2}\right)$ were estimated using the following equations (NYQUIST, 1991):

$$
\mathrm{h}^{2}{ }_{\mathrm{i}}=4 \times{\sigma^{2}}_{\mathrm{f}}^{2} /\left(\sigma^{2}+\sigma_{\mathrm{b}}^{2}+\sigma_{\mathrm{fb}}^{2}+\sigma_{\mathrm{f}}^{2}\right)
$$

$$
\begin{aligned}
\mathrm{h}_{\mathrm{f}}^{2} & =\sigma_{\mathrm{f}}^{2} /\left(\sigma^{2}+\mathrm{k}_{3}\left(\sigma^{2}{ }_{\mathrm{fb}}+\sigma_{{ }_{\mathrm{b}}}^{2}\right)+\mathrm{k}_{4} \sigma_{\mathrm{f}}^{2}\right) / \mathrm{k}_{4} \\
& =\sigma_{\mathrm{f}}^{2} /\left(\left(\sigma^{2} / \mathrm{k}_{4}\right)+\left(\sigma^{2}{ }_{\mathrm{b}}+\sigma^{2}{ }_{\mathrm{fb}}\right) /\left(\mathrm{k}_{4} / \mathrm{k}_{3}\right)+\sigma_{\mathrm{f}}^{2}\right)(\text { Table 2) }
\end{aligned}
$$

The inclusion of $\sigma^{2}{ }_{\mathrm{b}}$ in calculating family heritability is debatable (NYQUIST, 1991). Site variation in different locations in the mountainous terrain is largely random, which makes it ineffective to stratify the land base into manageable and meaningful strata according to site factors. Test sites in different locations from the site that we analyzed will most likely encounter the same type of variation represented by the blocks within the site, though perhaps with differing magnitudes. We included both $\sigma_{b}^{2}$ and $\sigma^{2}{ }_{\text {fb }}$ mainly to compensate for the lack of site replication in our study. Including $\sigma^{2}{ }_{b}$ only slightly affected the heritability estimates (e.g. age 21 individual-tree heritability for $\mathrm{DBH}$ with and without the $\sigma^{2}{ }_{\mathrm{b}}$ were, respectively, 0.492 and 0.501 ).

We calculated genetic correlations and genetic responses to selection only at the family level because individual tree identities were missing at age 21 (the target age of selection). Also the focus of our analysis is to evaluate the family (backward) selection for the operational tree improvement of the species (see Discussion). Age-age genetic correlations of family means for both between- and within-traits are calculated with the following equation:

$$
R_{x y}=\operatorname{cov}(x y) /\left(\sigma_{x} \sigma_{y}\right) \text {, }
$$

where, $\operatorname{cov}(\mathrm{xy})$ is the covariance between early $(\mathrm{x})$ and target $(\mathrm{y})$ age of the same trait or different traits, and $\sigma_{\mathrm{x}}$ and $\sigma_{\mathrm{y}}$ the square root of their family components.

The family selection calculations for genetic gains are based on the following equations:

$\mathrm{G}=\mathrm{i} \times \mathrm{h}_{\mathrm{f}}^{2} \times\left(\sigma^{2} / \mathrm{k}_{4}+\left(\sigma_{\mathrm{b}}^{2}+\sigma_{\mathrm{fb}}^{2}\right) /\left(\mathrm{k}_{4} / \mathrm{k}_{3}\right)+\sigma_{\mathrm{f}}^{2}\right)^{1 / 2}$ for direct selections at the different age individually (NAMKOONG et al., 1966), and

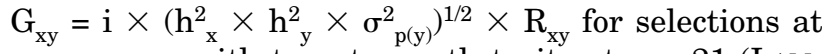

\begin{tabular}{|c|c|c|c|c|c|c|}
\hline \multicolumn{7}{|c|}{ Plantation Age (years) } \\
\hline \multicolumn{7}{|c|}{ Varianee Component $(\%)$} \\
\hline Source & 4.0 & 5.0 & 6.0 & 7.0 & 8.0 & 21.0 \\
\hline Block & $26(19)$ & $24(10)$ & $34(10)$ & $25(7)$ & $26(5)$ & $12(1)^{i}$ \\
\hline Family & $28(21)$ & $33(14)$ & $55(16)$ & $53(15)$ & $79(16)$ & $127(9)$ \\
\hline Block $\times$ Family & $40(29)$ & $25(11)$ & $32(9)$ & $31(9)$ & $55(11)$ & $257(18)$ \\
\hline Error & $44(31)$ & $154(65)$ & $222(65)$ & $236(68)$ & $337(68)$ & $1045(72)$ \\
\hline Frror Df & 709 & 2333 & 2285 & 2247 & 2198 & 1189 \\
\hline \multicolumn{7}{|c|}{ Heritability } \\
\hline$\overline{h_{i}}$ & 0.821 & 0.556 & 0.643 & 0.617 & 0.638 & 0.352 \\
\hline$h_{r}$ & 0.629 & 0.692 & 0.731 & 0.738 & 0.744 & 0.534 \\
\hline
\end{tabular}
younger ages with target growth traits at age 21 (LAM-

Table 3. - Variance components ( $\mathrm{VC} \times 100)$, also presented as intra-class correlations (\% of total variance), and individual $\left(\mathrm{h}_{\mathrm{i}}\right)$ and family $\left(\mathrm{h}_{\mathrm{f}}\right)$ heritability for total height at different ages.

a The variance component is not statistically significant at the 0.05 level, otherwise it is significant. 
BETH, 1980) or indirect selections between traits at the same age, where $\mathrm{i}=0.956$ assuming a selection intensity of retaining 30 out of the 75 parent trees in the seed orchard (the clonal seed orchard was established in 1971, two years before the progeny test) (NAMKOONG and SNYDER, 1969); $\mathrm{h}^{2}{ }_{\mathrm{x}}$ and $\mathrm{h}^{2}{ }_{\mathrm{y}}$ are the family heritabilities at the age when the selection was made and at the target age, respectively. For indirect between-trait selection at the same age, they are family heritabilities for trait $\mathrm{x}$ and $y$, respectively; $\sigma^{2}$ is is the phenotypic variance of the target trait as defined in $\mathrm{h}_{\mathrm{f}}^{2}$ and $\mathrm{R}_{\mathrm{xy}}$ the family correlation as described above.
We employed the above analytical approach considering its relevance to the situation in operational tree improvement in Taiwan (see Discussion) and constraints of the data, an operational mode of analysis (SEARLE, 1971; NYQUIST, 1991).

\section{Results}

Variance components and heritability estimates for HT, DBH and VOL are shown in Tables 3 to 5 (we did not report the results before age 4 for better betweentrait comparisons in age trend); all the effects were sta-

Table 4. - Variance components $(\mathrm{VC} \times 100)$, also presented as intra-class correlations $(\%$ of total variance), and individual $\left(\mathrm{h}_{\mathrm{i}}\right)$ and family $\left(\mathrm{h}_{\mathrm{f}}\right)$ heritability for DBH at different ages.

\begin{tabular}{|c|c|c|c|c|c|c|}
\hline \multicolumn{7}{|c|}{ Plantalion Age (years) } \\
\hline \multicolumn{7}{|c|}{ Variance Componern $(\% / \%)^{4}$} \\
\hline Source & 5.0 & 6.0 & 7.0 & 8.0 & 14.0 & 21,0 \\
\hline Block & $28(4)$ & $70(5)$ & $42(3)$ & $23(1)$ & $76(2)$ & $86(2)$ \\
\hline Family & $77(10)$ & $160(12)$ & $197(13)$ & $256(14)$ & $420(14)$ & $592(12)$ \\
\hline Block $\times$ Family & $92(11)$ & $80(6)$ & $86(6)$ & $89(5)$ & $70(2)$ & $201(4)$ \\
\hline Frror & $597(75)$ & $986(76)$ & $1218(79)$ & $1494(80)$ & $2533(82)$ & $3932(82)$ \\
\hline E.rror Df & 2273 & 2272 & 2246 & 2196 & 2096 & 1198 \\
\hline \multicolumn{7}{|c|}{ Ileritability } \\
\hline$\overline{h_{i}}$ & 0.387 & 0.495 & 0.512 & 0.550 & 0.542 & 0.492 \\
\hline$h_{r}$ & 0.632 & 0.718 & 0.749 & 0.780 & 0.783 & 0.687 \\
\hline
\end{tabular}

${ }^{\text {a }}$ All variance components are significant at the 0.05 level.

Table 5. - Variance components (VC), also presented as intra-class correlations (\% of total variance), and individual-tree $\left(\mathrm{h}_{\mathrm{i}}\right)$ and family $\left(\mathrm{h}_{\mathrm{f}}\right)$ heritability for total volume $\left(\mathrm{dm}^{3}\right)$ at different ages.

\begin{tabular}{|c|c|c|c|c|c|}
\hline \multicolumn{6}{|c|}{ Plancation age (years) } \\
\hline \multicolumn{6}{|c|}{ Variance component $(0 \%)^{\mathrm{a}}$} \\
\hline Soures & 5.0 & 6.0 & 7.0 & 8.0 & 21.0 \\
\hline Block & $6(5)$ & $34(7)$ & $35(4)$ & $57(3)$ & $835(2)$ \\
\hline Family & $10(8)$ & $48(10)$ & $95(11)$ & $237(12)$ & $5406(11)$ \\
\hline B1ock $\times$ Family & $16(13)$ & $33(7)$ & $55(7)$ & $111(6)$ & $2844(6)$ \\
\hline Error & $89(74)$ & $352(75)$ & $654(78)$ & $1536(79)$ & $38543(81)$ \\
\hline Error DI & 2273 & 2272 & 2246 & 2196 & 1188 \\
\hline \multicolumn{6}{|c|}{ Heritability } \\
\hline$h_{i}$ & 0.322 & 0.412 & 0.453 & 0.488 & 0.454 \\
\hline$h_{\mathbf{r}}$ & 0.573 & 0.660 & 0.711 & 0.739 & 0.659 \\
\hline
\end{tabular}

a All variance components are significant at the 0.05 level. 
Table 6. - Age-age genetic correlation of family means between early and target age at 21 within and between traits.

\begin{tabular}{|c|c|c|c|}
\hline & \multicolumn{3}{|c|}{ Iarget Irait } \\
\hline Selection Trait & HT (age 21.0) & [DBH (age 21) & VOL (age 21.0 ) \\
\hline IIT (uge 4.0) & 0.66 & -- & -- \\
\hline HT (age 5.0) & 0.68 & 0.51 & 0.44 \\
\hline $11 \mathrm{~T}$ (age 6.0 ) & 0.68 & 0.52 & 0.43 \\
\hline HT (age 7.0$)$ & 0.74 & 0.58 & 0.50 \\
\hline HT (age 8.0$)$ & 0.74 & 0.56 & 0.47 \\
\hline 111 (age 21.0 ) & 1.00 & 0.87 & 0.81 \\
\hline DBH (age 5.0) & 0.77 & 0.74 & 0.70 \\
\hline $\mathrm{DBH}(\mathrm{agc} 6.0)$ & 0.79 & 0.81 & 0.75 \\
\hline DВH (age 7.0 ) & 0.79 & 0.81 & 0.77 \\
\hline DBI (age 8.0) & 0.82 & 0.85 & 0.81 \\
\hline DBI (age 14.0) & -- & 0.95 & -- \\
\hline DBH (age 21.0) & 0.87 & 1.00 & 1.00 \\
\hline Vor, (age 500$)$ & -- & -- & 0.76 \\
\hline VOL $(\operatorname{age} 6.0)$ & -- & -- & 0.77 \\
\hline $\mathrm{V}(0 \mathrm{~L}$ (age 7.0$)$ & -- & -- & $0 . \$ 1$ \\
\hline VOI (age 8.0 ) & -- & -- & 0.85 \\
\hline VOI (agc 21.0$)$ & -- & -- & 1.00 \\
\hline
\end{tabular}

tistically significant at probability 0.05 except the effect of block at age 21 (Table 3). The family VC for height stabilized at around $15 \%$ from age 5 to 8 , and then dropped to $9 \%$ at age 21 . The size of the family-block interaction VC showed a similar trend, becoming stable at about $10 \%$ from ages 5 to 8 , and then a sharp increase to $18 \%$ at age 21 . The family-block interaction and error VCs together accounted for about $75 \%$ of the total variance for most years. The VCs for DBH (Table 4 ), on the other hand, showed a high degree of stability with age compared to that for height; the family component varied from 10 to $14 \%$ of the total variance from age 5 to 21 . Both family-block interaction and error components were remarkably stable over the age range, and together accounted for about $85 \%$ of the total variation (Table 4). Within the same age range, the size of the block effect for height was not only substantially larger but also more variable than that for $\mathrm{DBH}$ ( 1 to $10 \%$ vs. 1 to $5 \%$ from age 5 to 21 ) (Table 3 and 4 ). Both the size and stability of the block and family-block interaction VCs suggested that height growth was more sensitive to within-site environments than $\mathrm{DBH}$. The $\mathrm{VC}$ age trend for volume (Table 5) essentially followed that of $\mathrm{DBH}$. This is expected since $\mathrm{DBH}$ is more related to volume (CHung et al., 2009). Again, the family-block and error components combined accounted for about $85 \%$ of the total variance. With such a high within-plot variance, individual tree selection for any of the growth traits in this test cannot be expected to be effective.

Individual tree heritability for height (Table 3) remained at about 0.6 for most of the years except at age 4 , and a sharp drop at age 21 to 0.35 ; family heritability was relatively stable over time, varying from 0.5 to 0.7 . The trend for both individual and family heritability for $\mathrm{DBH}$ (Table 4) was stable without the sharp drop from age 8 to 21 as seen for height. Heritability stabilized at around 0.5 for individuals and at 0.7 for the families after age 5. Volume heritability showed a similar age trend as $\mathrm{DBH}$, and, after age 5, stabilized at around 0.45 for individual heritability and around 0.7 for family heritability (Table 5).

The family genetic correlation (Table 6) between early and target ages within traits increased as age approached the target age of 21 years. Correlation coefficients were higher for DBH than for height and volume at the same early ages. Between-trait correlations associated with $\mathrm{DBH}$ at the same age combinations were also higher than others, e.g. at age 21 , DBH-volume genetic correlations were 1.00 , compared to 0.81 for height-volume. Genetic correlations (Table 6) clearly indicate that selection on $\mathrm{DBH}$ can be highly effective to achieve a genetic gain in growth. Indeed, predicted responses to selection on $\mathrm{DBH}$ in either a direct or indi-

Table 7. - Genetic gains (\% of target trait in parentheses) at target age 21 from within- and between-trait family selection at early and target ages.

\begin{tabular}{|c|c|c|c|}
\hline \multirow[b]{2}{*}{ Sclcction Trail } & \multicolumn{3}{|c|}{ Target Trait } \\
\hline & IIT (agc 21.0) & Г७ВГ $(\operatorname{agc} 21.6)$ & VOT. (age 21,0) \\
\hline HT (age 4.0$)$ & $0.57(3.7)$ & -- & -- \\
\hline IIT (uge 5.0) & $0.61(4.0)$ & $0.99(5.9)$ & $25.67(9.2)$ \\
\hline 1HT (age 6.0$)$ & $0.62(4.1)$ & $1.02(5.1)$ & $25.83(9.3)$ \\
\hline HT (age 7.0$)$ & $0.69(4.5)$ & $1.15(5.7)$ & $30.46(10.9)$ \\
\hline IIT (age 8.0) & $0.69(4.5)$ & $1.12(5.6)$ & $28.26(10.2)$ \\
\hline $\mathrm{HI}(\mathrm{ngc} 21.0)$ & $0.79(5.2)$ & $1.48(7.3)$ & $41.81(15.0)$ \\
\hline DBH (age 5.0) & $0.66(4.4)$ & $1.38(6.8)$ & $39.07(14.1)$ \\
\hline DHBH $($ age $(1.0)$ & $0.72(4.7)$ & ] $.60(7.9)$ & $44.4(16.0)$ \\
\hline DPHI (are 7.0 ) & $0.74(4.9)$ & $1.63(8.1)$ & $46.8(16.8)$ \\
\hline DHH (age 8.0) & $0.78(5.1)$ & $1.75(8.7)$ & $50.35(18.1)$ \\
\hline DBH (age 14.0 ) & -- & $1.96(9.7)$ & -- \\
\hline DBH (age 21.0) & $0.79(5.1)$ & $1.93(9.6)$ & $58.40(21.0)$ \\
\hline Vol. (agre 5.0 ) & -- & -- & $40.91(14.7)$ \\
\hline VOl. (age 6.0$)$ & -- & -- & $44.87(16.1)$ \\
\hline Vol. (age 7.0 ) & -- & -- & $48.76(17.5)$ \\
\hline VOT. $(\operatorname{agc} 8.0)$ & -- & -- & $52.11(18.7)$ \\
\hline $\operatorname{VOL}(\operatorname{agc} 21.0)$ & -- & -- & $57.97(20.1)$ \\
\hline
\end{tabular}


rect manner were higher than on height or volume (Table 7). Selection on DBH at age 21 would result in $21.0 \%$ gain in volume and $5.1 \%$ in height, compared to a gain of $20.1 \%$ from direct selection for the former and $5.2 \%$ the latter. On the other hand, selection on height would result in a $15.0 \%$ gain in volume and $7.3 \%$ gain in $\mathrm{DBH}$, while a direct selection on $\mathrm{DBH}$ would produce a $9.6 \%$ gain (Table 7 ). Judging from the incremental trend in percentage gain from selecting at early ages (Table 7), selection could start after age 8 .

\section{Discussion}

Konishii fir is fast growing and genetically variable (Tables 3-5) despite its limited geographic range (Figure 1). Selection for genetic improvement of growth can be expected to be effective. Gain from family selection (i.e. roguing the existing clonal seed orchard) can yield a $20 \%$ increase in volume (Table 7 ), which may be optimistic because they were based on a single site. How ever, with family-structured open pollinated progeny testing, backward selection is expected to be reliable (Ruotsalainen and Lindgren, 1998; HAAPANEN, 2001). The selection of the 30 parental trees is mainly for some immediate gain for plantations, but not large enough to sustain a long-term breeding program (JAYAWICKRAMA and CARLSON, 2000; ERIKSSON et al., 2006). The genetic base needs to be substantially broadened (see below).

The analysis of the variance components and heritability both indicate that $\mathrm{DBH}$ is genetically more stable than height over time (Tables 3 and 4). Costa and DUREL (1996) found similar results in maritime pine (Pinus pinaster) and GwAZE and BRIDGwATER (2002) in loblolly pine (Pinus taeda), and they suggest that the genetic regulation on eco-physiological processes resulting in height growth may be different from those resulting in diameter growth.

CoRNELIUS (1994) broadly reviewed individual tree heritability in forest tree species; our estimates at age 21 were higher than his means $(0.35,0.49$, and 0.45 vs $0.28,0.23$, and 0.21 , respectively, for height, $\mathrm{DBH}$, and volume), but were within the ranges of their normal distributions (approximately 0.1-0.5). More recent reports also showed individual tree heritability is mostly within the range cited in the Cornelius review, e.g. Coastal Douglas-fir (Pseudotsuga menziesii) (JoHnson et al., 1997), maritime pine (KUSNANDAR et al., 1998), and lobololly pine (GWAZE and BRIDGWATER, 2002).

The test trees averaged $15.2 \mathrm{~m}$ in height (range: $12.5-17.1 \mathrm{~m}), 20.2 \mathrm{~cm}$ in DBH $(14.9-24.3 \mathrm{~cm})$, and 278 $\mathrm{dm}^{3}$ in volume $\left(148.4-422.4 \mathrm{dm}^{3}\right.$ ) at age 21 (before the typhoon). This growth is comparable to that found in a similar genetic trial located at a higher elevation (1,300 m) involving 18 families (at age 25 , the average height was $15.2 \mathrm{~m}, \mathrm{DBH}$ was $27.7 \mathrm{~cm}$, and volume was $300 \mathrm{dm}^{3}$ ) (Su, 2004), and that of KUO (1995) (at an intermediate site class at age 20 , height was $15.7 \mathrm{~m}, \mathrm{DBH}$ was $28.0 \mathrm{~cm}$, and volume was $530 \mathrm{dm}^{3}$ ), and similar to that of its sister species, China fir (height, $\mathrm{DBH}$, and volume at age 20 were $17.2 \mathrm{~m}, 20.8 \mathrm{~cm}$ and $310 \mathrm{dm}^{3}$, respectively) (LIU et al., 1979). The average growth from a single test, though, is probably representative of the species and its genetic gain estimates at age 21 (Table 7) are likely good indicators of gains at a typical harvesting age of 30 years.

Compared to the growth of coniferous species in other regions, Konishii fir is substantially more productive than fast growing temperate conifers, e.g. western larch (Larix occidentalis) (top height $6.7 \mathrm{~m}$ at age 20 on a site index $20 \mathrm{~m}$ site) (BRISCO et al., 2002), and coastal Douglas-fir (top height $11.2 \mathrm{~m}$ at total age 20 on a site index $34 \mathrm{~m}$ site) (NiGH and Mitchell, 2003). Konishii fir has height growth that is comparable to southern pines in the United States, e.g. loblolly and longleaf (Pinus palustris) pine with top heights of $17.6 \mathrm{~m}$ and $17.3 \mathrm{~m}$, respectively, at age 21 on good sites (CAO et al., 1997).

Diameter should be used as the primary trait in selection since selecting on DBH either directly or indirectly can be more effective than selecting on either height or volume (Table 7). Diameter growth is also less vulnerable to injuries caused by typhoons, which occur almost yearly in Taiwan and often cause severe damage to plantations. Typhoons, like fires in the temperate forests, are a natural agent that is essential to the renewal of natural ecosystems. Unlike fires, however, they cannot be controlled or prevented. CHung et al. (2009) found a very different pattern of growth between height and diameter based on growth curve fitting using a subset of the same data as in this analysis. Diameter growth was well into the asymptotic phase at age 21 , whereas height was still increasing at the same age. Therefore, diameter can serve as better indicator of the gain at harvesting age at about 30 years.

Our study, having a single test site, naturally leads to the question of whether a progeny-site environment interaction (i.e., GxE) exists. The practical application of $\mathrm{GxE}$ is for breeding zone delineation as means to reduce the within-zone GxE in order to enhance genetic gain in operational tree improvement. For this purpose, the $\mathrm{GxE}$ has to be classifiable according to its cause-effect association with site environmental factors and can be efficiently administered (NYQUIST, 1991). HAAPANEN (2001) did one of the most comprehensive analysis of such an interaction involving over 100,000 trees from over 300 families of Scots pine in 26 tests with different planting spacing in different edaphic site conditions in Finland; the results still failed to shed evidence of a cause-effect correlation of genetic parameters with site characters. Cause-effect relationship in GxE is difficult to delineate, except it is related to a broad regional climate (WU and YING, 2004); In Taiwan with its limited land base and a mountainous terrain, such breeding zone delineation can be difficult and costly. From a costbenefit perspective, multiple breeding zones is not a viable option for any operational tree improvement in Taiwan, even if substantial GxE exists (JAYAWICKRAMA and CARLson, 2000; HaApanen, 2001; Dean, 2007). However, the above does not suggest multiple tests to provide precision estimates of genetic parameters and gain is not needed.

We did not do an in-depth analysis to determine the optimal age of selection. There is not yet a quantitative method that is applicable in all situations. The LAMBETH 
(1980) model is probably the most commonly used model in quantifying the optimal age of selection. However, the model has a built-in bias in favour of selecting at younger ages when gain per unit time is the criterion (CHEN et al., 2003), and the juvenile-mature correlation is based on time rather than biological process of tree growth (MAGNUSSEN, 1989). Using growth curve analysis techniques to determine the optimal age of selection (e.g. Magnussen, 1989; Magnussen and ParK, 1991; MAGNUSSEN and KREMER, 1993) is often complex conceptually and mathematically, and therefore, this approach is not commonly used. With Konishii fir, selection can start any time between ages 8 and 14 based on the time trend in age-age correlations (Table 6) and projected gains (Table 7), particularly if the selection is made on $\mathrm{DBH}$ (no further gain in diameter growth after age 14). Chung et al. (2009) recommend early selection at around age 10 when the diameter growth is entering into the asymptotic phase.

One immediate concern about selecting for genetic gain in growth is the negative effect of rapid growth on wood density; the market value of Konishii fir is tied to the quality of its wood. Wood density is the indicator trait of quality wood (ZOBEL and VAN BUIJTENEN, 1989). In particular, plantations today may encounter warmer climates and hence grow faster, resulting in less dense wood (StOEHR et al., 2009). Forty-eight out of the 75 families from the same test were assessed for wood density at age 25 by YANG et al. (2001); the average density was 0.36 . Out of the 30 families selected, either on $\mathrm{DBH}$, height, or volume, about 27 of them happen to be included in the wood density assessment; their average density was 0.35 . We thus expect the production population consisting of these 30 parent trees in the rogued seed orchard will maintain the average wood density of the species. This was one factor that we took into consideration when we opted for a low selection intensity $(\mathrm{i}=0.956)$ in our analyses.

Tree improvement is a proven enterprise for investment; there are many successful programs worldwide, including the coastal Douglas-fir program in British Columbia, Canada (STOEHR et al., 2010), the radiata pine in New Zealand (JAYAWICKRAMA and CARLSON, 2000), and loblolly pine in the southern United States (DougherTy and WRIGHT, 2009). These programs can be useful models for tree improvement in Taiwan. Successful tree improvement has to be a long term proposition which evolves and progresses depending on a large extent on the accumulation of local knowledge and experience (JAYAWICKRAMA and CARLSON, 2000). Tree improvement does not necessarily need a complicated scheme at the start; a simple recurrent selection may be sufficient (ERIKSSON et al., 2006). One advantage of Konishii fir is that the seed orchard is already producing a commercial quantity of seed; an operational tree improvement program can be launched with an immediate, although perhaps modest, gain. Taiwan's tree improvement program has lost three decades. The sooner the program can get back on track, the better.

The main purpose of this research was to provide guidance on making informed decision regarding the operational tree improvement of Konishii fir. We conclude by recommending:

1) The expansion of breeding and selection including China fir. Konishii fir is genetically variable and fast growing which makes it a suitable candidate for operational tree improvement (ERIKSsON et al., 2006). China fir has been planted in Taiwan for centuries and is a land race. No reproductive barrier exists between Konishii and China fir (YANG and CHUNG, 1999). Including China fir broadens the genetic basis and also expands the potential land base for plantations, the latter a major barrier to operational tree improvement in Taiwan. The genetic combination of Konishii-China fir is expected to be productive in the low elevation foothills, where economic crops of fruit trees and vegetables were once planted. These labour intensive crops are no longer profitable.

2) Roguing the clonal seed orchard to retain about 30 parental clones with the best progeny performance for seed production and some immediate genetic gain.

3) Establishing multi-site progeny trials (including China fir) at representative locations to enable efficient assessment of the magnitude of site variation and classifiable progeny-site interactions for the long-term benefits of genetic improvement (HAAPANEN, 2001).

4) Developing a general breeding strategy using realistic approaches that consider both technical and administrative structures and be flexible to allow progressive changes of the program in the long term ((JAYAWICKRAMA and CARLsON, 2000; ERIKSson et al., 2006).

Taiwan is rich in forest flora. On wood property alone, a number of species could be candidate species for tree improvement. Unfortunately, all the top candidate species seem to have certain undesirable silvicultural or biological characteristics, for example, Chamaecyparis formosensis, and $C$. obtuse tend to grow poor stem form and excessive branches in plantations, and Calocedrus formosana and Taiwania cryptomerioides are reproductively late mature species, cone production starts at about age 30 for the former (CHUNG et al., 2001), and at 45 for the later (LIU and Su, 1983). These undesirable characteristics have hindered efforts to improve these species employing genetic breeding. Again, with limited land base for plantation forests, a multiple-species breeding program is probably not a realistic option, economically.

\section{Acknowledgements}

The late Dr. Hu TA-WEI, Taiwan Forestry Research Institute organized and established the trial. We thank the National Science Council of Taiwan for visiting grant (NSC 95-2811-B-054-002) to C. C. YING. Dr. Michael StoenR, Research Branch, Ministry of Forests, reviewed the early version of the manscript. We thank the reviewer's comprehensive and helpful review..

\section{References}

BRISCO, B., K. KLINKA and G. NiGH (2002): Height growth models for western larch in British Columbia. Western Journal of Applied Forestry 17: 66-74. 
CAO, Q. V., V. C. BALDWIN, JR. and R. E. LOHREY (1997): Site index curves for direct-seeded loblolly and longleaf pine in Louisiana. Southern Journal of Applied Forestry 21: 134-138.

Chang, L. M., W. F. LIN and T. LIU (1979): Forest Plants in Taiwan (in Chinese). Quarterly Journal of Chinese Forestry 1: 1-78.

Chen, X. Y., B. Hawkins, C. Y. XIE and C. C. YInG (2003): Age trends in genetic parameters and early selection of lodgepole pine provenance with reference to the Lambeth model. Forest Genetics 10: 249-258.

Chung, J. D., C. T. Chien, G. Nigh and C. C. YING (2009): Variation in growth curve parameters of Konishii fir (Cunninghamia lanceolata (Lamb.) Hook. var. konishii). Silvae Genetica 58: 1-10.

Chung, J. D., T. P. Lin, Y. C. TAN, M. Y. Lin and S. Y. HWANG (2004): Genetic diversity and biogeography of Cunninghamia konishii (Cupressaceae), an island species in Taiwan: a comparison with C. lanceolata, a mainland species in China. Molecular Phylogenetics and Evolution 33: 791-801.

Chung, J. D., S. R. Kuo and J. C. YANG (2001): Preliminary results of flowering promotion and seeding in reestablished clonal seed orchards of Calocedrus for mosana. (in Chinese with English summary). Taiwan Journal of Forest Science 16: 181-196.

CoRnelius, J. (1994): Heritabilities and additive coefficients of variation in forest trees. Canadian Journal of Forest Research 24: 372-379.

CostA, P. and C. E. Durel (1996): Time trends in genetic control over height and diameter in maritime pine. Canadian Journal Forest Research 26: 1209-1217.

DEAN, C. A. (2007): Genotype and population performances and their interactions for growth of Coastal Douglas-fir in western Washington. Forest Science 53: 463-472.

DOUGHTER, D. and J. WRIGHT (2009): Improved returns of forestlands: a financial analysis of mass pollinated and variety seedlings. Tree Farmer January/February: 42-46.

ERIKSSON, G., I. EkBERG and D. Clapham (2006): An Introduction to Forest Genetics. Genetic Center, Department of Plant Biology and Forest Genetics, SLU, Uppsala, Sweden

FENG, F. L. and M. R. JENG (1992): Volume equations for major timber species in Taiwan (in Chinese). Department of Forestry, Taichung, Taiwan: National Chung Hsing University, Taichung, Taiwan.

Gwaze, D. P. and F. E. BRIDGWATER (2002): Determining the optimum selection age for diameter and height in loblolly pine. Forest Genetics 9: 159-165.

HAAPANEN, M. (2001): Time trends in genetic parameters and selection efficiency for scots pine in relation to field test method. Forest Genetics 8: 129-144.

HsU, H.-H. and C.-T. CHEN (2002): Observed and predicted climate change in Taiwan. Meteorol. Atmos. Phys. 79: 87-104.

HsU, K. S., Y. C. Song and S. Y. LIU (2004): Classification of Forest Vegetation in Taiwan. Taiwan National Museum of Natural Sciences. Taipei, Taiwan.

Hwang, S. Y., T. P. LiN, C. S. MA and C. L. LIN (2003): Postglacial population growth of Cunninghamia konishii (Cupressaceae) inferred from phylogeographical and mismatch analysis of chloroplast DNA variation. Molecular Ecology 12: 2689-2695.
JAYAWICKRAMA, K. J. S. and M. J. CARSON (2000): A breeding strategy for the New Zealand radiata pine breeding cooperative. Silvae Genetica 49: 82-90.

Johnson, G. R., R. A. SNiezko and N. L. MANDEL (1997): Age trends in Douglas-fir genetic parameters and implications for optimum selection age. Silvae Genetica 46: 349-358.

Kuo, P. T. (1995): Major Timber Tree Species in Taiwan (in Chinese). Chinese Forestry Association Bulletin No. 965, Taipei, Taiwan.

Kusnandar, D., N. W. Galwey, G. L. Hertzler and T. B. Butcher (1998): Age trends in variances and heritabilities for diameter and height in maritime pine (Pinus pinaster Ait.) in Western Australia. Silvae Genetica 47: 136-141.

LAMBETH, C. C. (1980): Juvenile-mature correlation in Pinaceae and its implications for early selection. Forest Science 26: 571-580.

LIN, T. P., C. T. WANG and J. C. YANG (1998): Comparison of genetic diversity between Cunninghamia Konishii and C. lanceolata. Journal of Heredity 89: 370-373.

Littell, R. C., G. A. Milliken, W. W. Stroup and R. D. WolfINGER (1996): SAS System for Mixed Models. SAS Institute Inc., Cary, NC, USA.

LiU, T. (1972): The forest vegetation of Taiwan, pp. 55-85 in Forest Ecology and Genetics seminar, US-China Cooperative Science Program. Taipei, Taiwan.

LIU, T. S. and H. J. Su (1983): Biosystematic studies on Taiwania and numerical evaluations on the systematics of Taxodiaceae. Taiwan Museum Special Publication Series No. 2. The Taiwan Museum, Taipei, Taiwan

LIU, Y. C., W. Z. LIN and W. Z. LIN (1979): Silviculture of Timber Tree Species in Taiwan (in Chinese). National Chung Hsing Univeristy, College of Agriculture, Taichung, Taiwan.

LIU, Y. C., F. Y. LU and C. H. OU (1988): Trees of Taiwan (in Chinese). National Chung Hsing Univeristy, College of Agriculture, Taichung, Taiwan. Monograph No. 7.

LU, S. Y., T. Y. Chiang, K. H. HoNG and T. W. Hu (1999): Re-examination of the taxonomic status of Cunninghamia konishii and C. lanceolata based on the RFLPs of a chloroplast trnD-trnT spacer. Taiwan Journal of Forest Science 14: 13-19.

Magnussen, S. (1989): Age-age correlations in growth processes with fixed and random effects. Silvae Genetica 38: $49-55$.

Magnussen, S. and A. KREMer (1993): Selection for an optimum growth curve. Silvae Genetica 42: 322-335.

MAGnussen, S. and Y. S. PARK (1991): Growth-curve differentiation among Japanese larch provenances. Canadian Journal of Forest Research 21: 504-513.

NAmkoong, G., E. B. SNyder and R. W. Stonecypher (1966): Heritability and gain concepts for evaluating breeding systems such as seedling orchards. Silvae Genetica 15: 76-84.

NAMKOONG, G. and E. B. SNyder (1969): Accurate values for selection intensities. Silvae Genetica 18: 171-173.

Nigh, G. D. and M. G. E. Mitchell (2003): Development of height-age models for estimating juvenile height of coastal Douglas-fir in British Columbia. Western Journal of Applied Forestry 18: 207-212.

NYQUIST, W. E. (1991): Estimation of heritability and prediction of selection response in plant popuations. Critical Review in Plant Sciences 10: 235-322. 
Quan, B. T., C.-H. Chung, S.-T. Lin and C.-W. Shen (2009): Quantifying height growth and monthly growing degree days relationship of plantation Taiwan spruce. Forest Ecology and Management. 257: 2270-2276.

Ruotsalainen, S. and D. LindGREN (1998): Predicting genetic gain of backward and forward selection in forest tree breeding. Silvae Genetica 47: 42-50.

SEARLE, S. L. (1971): Topics in variance component estimation. Biometrics 27: 1-76.

Stoehr, M. U., K. Bird, G. Nigh, J. Woods and A. YANCHUK (2010): Realized Genetic Gains in Coastal Douglas-fir in British Columbia: Implications for growth and yield projections. Silvae Genetica 59: 223-233

Stoehr, M. U., N. K. Ukrainetz, L. K. HaYton and A. D. YANCHUK (2009): Current and future trends in juvenile woood density for coastal Douglas-fir. Canadian Journal of Forest Research 39: 1415-1419.

Su, L-H (2004): Estimating breeding values and genetic gain of Cunninghamia lanceolata (Lamb.) Hook. var. Konishii from a 27-year progeny test with messy data. Master Thesis (in Chinese with English summary),
Department of Forestry, College of Agriculture and Natural Resources, National Chung Hsing University, Taichung, Taiwan.

TsuKADA, M. (1967): Vegetation in subtropical Formosa during the Pleistocene glaciation and the Holocene. Palaeogeography, Palaeoclimatology, Palaeoecology 3: 49-64.

WU, H. X. and C. C. YING (2004): Geographic pattern of local optimality in natural populations of lodgepole pine. Forest Ecology and Managemnt 194: 177-198.

YANG, J. C. and J. D. ChUNG (1999): Preliminary study on hybridity among Cunninghamia lanceolata, Cunninghamia konishii, Cryptomeria japonica, and Taiwania cryptomerioides (in Chinese with English summary). Taiwan Journal of Forest Science 14: 437-446.

YANG, J. C., C. H. LeE and C. M. ChIU (2001): Genetic variation of wood density in Luanta fir tested in central Taiwan. Wood and Fiber Science 33: 486-491.

Zobel, B. J and J. P. VAN BuiJTEnen (1989): Wood variation: its causes and control. Springer-Verlag, New York, NY.

\title{
The effectiveness of phenotypic selection in natural populations: a case study from the Peruvian Amazon
}

\author{
By J. P. Cornelius ${ }^{1, *}{ }^{*}$, C. Sotelo Montes ${ }^{2)}$, L. J. Ugarte-Guerra ${ }^{3)}$ and J. C. Weber ${ }^{2)}$
}

(Received $3^{\text {rd }}$ September 2010)

\begin{abstract}
Phenotypic selection is commonly used in agroforestry, both in genetic improvement and as a component of "good practice" in seed collection. In the first case, the aim is to secure genetic gain. In the second case, selection is used to ensure that seed supplies meet given minimum quality standards, or that poor quality sources are avoided. Here we examine the effectiveness of phenotypic selection in natural forest stands of the Amazonian timber and multipurpose tree Calycophyllum spruceanum Benth.. We ask (a) whether mothertrees with high estimated annual height and diameter increments had faster growing progeny than mothertrees with low values; (b) whether forked mother-trees tended to have higher proportions of forked progeny than unforked trees; (c) whether spatially isolated moth-
\end{abstract}

\footnotetext{
1) Agroforestry and Novel Crops Unit, School of Marine and Trop ical Biology, James Cook University, P.O. Box 6811, Cairns, QLD 4870, Australia. E-Mail: jonathan.cornelius@jcu.edu.au.

${ }^{2}$ ) World Agroforestry Centre (ICRAF), West and Central Africa Sahel Office, B.P. E5118, Bamako, Mali.

3) World Agroforestry Centre (ICRAF), CIP, Apartado Postal 1558, Lima 12, Peru.

*) Communicating author: JonATHAN P. CoRnelius. Phone +61-7-40421789. E-Mail: jonathan.cornelius@jcu.edu.au.
}

er-trees tend to produce slower growing progeny than mother-trees growing together with conspecifics. In each case, we found no evidence of differences between the respective groups. We offer explanations for these findings and discuss their implications for tree improvement and seed collection.

Key words: Calycophyllum spruceanum, progeny-test, tree domestication, tree improvement, seed collection, tropical rainforest.

\section{Introduction}

Phenotypic selection is used commonly in agroforestry, both in genetic improvement programmes (e.g. MESÉN et al., 1994) and as a component of "good practice" in seed collection (e.g. MULAWARMAN et al., 2003). In the first case, the aim is to secure genetic gain. In the second case, selection is used to ensure that seed supplies meet given minimum quality standards, or that poor quality sources are avoided.

Phenotypic selection involves a cost. Therefore, its effectiveness is of interest. CoRnELIUS (1994a) established that plus-tree selection for yield can be effective. However, there were indications that selection is less effective in wild stands than in plantations. There are 